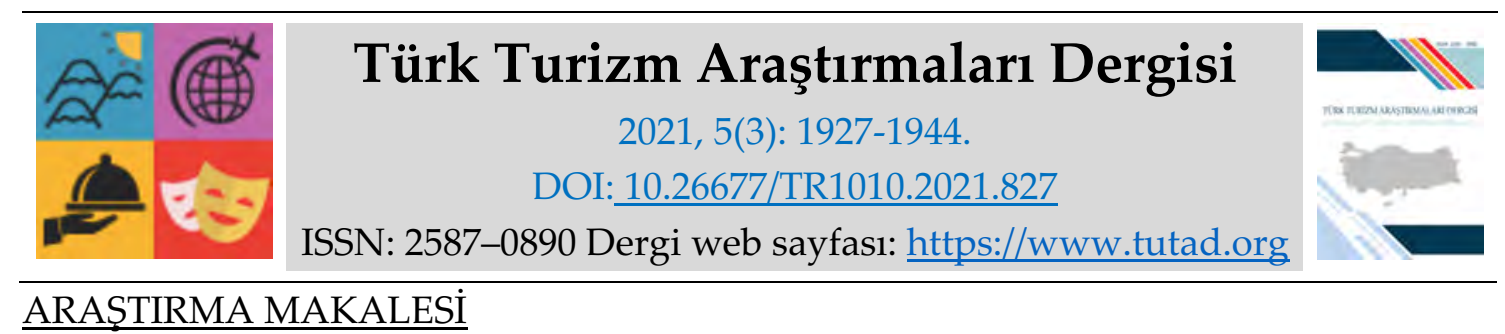

\title{
Otel İşletmelerinde Çevre Yönetim Sistemi Engelleyicileri Ölçeğinin Türkçeye Uyarlanmasi*
}

Doç. Dr. Ahmet BAYTOK, Afyon Kocatepe Üniversitesi, Turizm Fakültesi, Afyonkarahisar, eposta: ahmetbaytok@aku.edu.tr ORCID: https://orcid.org/0000-0002-5826-7694

Arş. Gör. Mehmet BOYRAZ, Afyon Kocatepe Üniversitesi, Turizm Fakültesi, Afyonkarahisar, eposta: mboyraz@aku.edu.tr ORCID: https://orcid.org/0000-0001-6755-1999

\section{Öz}

Bu araştırmanın amacı, Chan (2008) tarafından geliştirilen Çevre Yönetimi Sistemi Engelleyicileri (Barriers of Environmental Management Systems) Ölçeğinin Türkçeye uyarlanmasıdır. Likert tipi 28 ifadeden oluşan ölçme aracı, iç ve dış engeller olmak üzere altı faktörlü yapıdadır. Ölçeğin uyarlanması sürecinde ilk aşamada dil geçerliliği için uzmanlar eşliğinde orijinal dilinden (İngilizce) Türkçeye çeviri ve geri çeviri yapılmıştır. İkinci olarak kapsam geçerliliğini sağlamak için konuyla ilgili uzman görüşleri alınarak öneriler doğrultusunda ölçek ifadelerinde gerekli düzenlemeler gerçekleştirilmiştir. Böylelikle ölçek pilot uygulama için uygun hale getirilmiştir. Çalışmanın evreni, Türkiye'de faaliyet gösteren ve herhangi bir çevre yönetim sistemi, programı ya da ödülüne sahip olmayan 2339 otel işletmesini kapsamaktadır. Bu doğrultuda 1-28 Şubat 2021 tarihleri arasında kolayda örneklemeyle ulaşılan 400 otel işletmesinin orta ve üst düzey yöneticisi ise çalışmanın örneklemini oluşturmaktadır. Çalışmada toplanan verilere geçerlik, güvenirlik, madde ve korelasyon analizi ile açıklayıcı ve doğrulayıcı faktör analizleri yapılmıştır. Ulaşılan sonuçlara göre, ölçekteki ifadelerin orijinal boyutlarına paralel olarak altı boyut altında yer alarak geçerli ve güvenilir bir yapı gösterdiği tespit edilmiştir.

* Bu çalışma Afyon Kocatepe Üniversitesi Bilimsel Araştırma Projeleri Koordinasyon Birimi (BAPK) Tarafından Desteklenmekte olan ve Afyon Kocatepe Üniversitesi Sosyal Bilimler Enstitüsü Turizm İşletmeciliği Doktora Programı'nda yürütülen Mehmet BOYRAZ'ın doktora tezi araştırma verileri kullanılarak üretilmiştir.

Anahtar Kelimeler: Turizm ve Otel İşletmeleri, Çevre Yönetim Sistemi Engelleyicileri, Ölçek Uyarlama. Makale Gönderme Tarihi: 25.05.2021

Makale Kabul Tarihi: 03.09.2021

Önerilen Atıf:

Baytok, A. ve Boyraz, M. (2021). Otel İşletmelerinde Çevre Yönetim Sistemi Engelleyicileri Ölçeğinin Türkçeye Uyarlanması, Türk Turizm Araştırmaları Dergisi, 5(3): 1927-1944.

(c) 2021 Türk Turizm Araştırmaları Dergisi. 


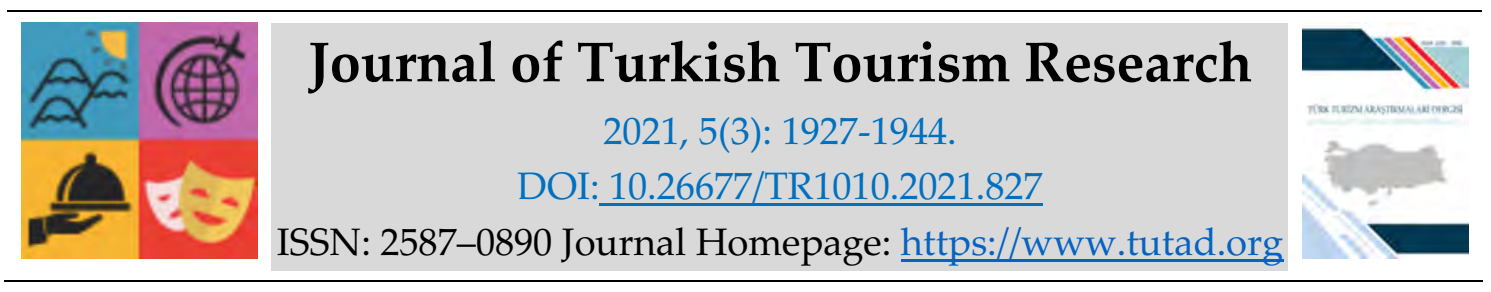

\title{
RESEARCH PAPER
}

\section{Adaptation of Barriers of Environmental Management System Scale in Hotel Enterprises to Turkish}

Associate Prof. Dr. Ahmet BAYTOK, Afyon Kocatepe University, Faculty of Tourism, Afyonkarahisar, e-mail: ahmetbaytok@aku.edu.tr ORCID: https://orcid.org/0000-0002-5826-7694

Research Assistant Mehmet BOYRAZ, Afyon Kocatepe University, Faculty of Tourism, Afyonkarahisar, e-mail: mboyraz@aku.edu.tr ORCID: https://orcid.org/0000-0001-6755-1999

\begin{abstract}
This research aims to adapt the Barriers of Environmental Management Systems Scale developed by Chan (2008) into Turkish. The scale, which consists of 28 Likert-type expressions, has six factors regarding internal and external barriers. In the first stage, the scale was translated to Turkish from its original language (English), then it was reverse translated too for language validity under the supervision of interpreters. Secondly, to ensure scope validity expert opinions were received, then finalize the expressions in scale has been given regarding their suggestion. Thus, the scale has been made suitable for the pilot application. The research population includes 2339 hotel enterprises operating in Turkey and do not have any environmental management system, program, or award. In this direction, middle and senior managers of 400 hotel businesses, which were reached by convenience sampling method between 1-28 February 2021, constitute the study sample. Validity, reliability, item and correlation analysis, and explanatory and confirmatory factor analyzes were carried out on the data collected in the study. According to the results, the expressions in the scale were placed under six dimensions, parallel with their original dimensions, and showed a valid and reliable structure.
\end{abstract}

Keywords: Tourism and Hotel Enterprises, Barriers of Environmental Management System, Scale Adaptation.

Received: 25.05 .2021

Accepted: 03.09.2021

\section{Suggested Citation:}

Baytok, A. and Boyraz, M. (2021). Adaptation of Barriers of Environmental Management System Scale in Hotel Enterprises to Turkish, Journal of Turkish Tourism Research, 5(3): 1927-1944.

(C) 2021 Türk Turizm Araştırmaları Dergisi. 


\section{Gíriş}

Sanayileşme, kentleşme ve hızlı nüfus artışı, yenilenemeyen kaynakların aşırı derecede tüketilmesi, küresel hava kirliliği, sera etkisi, ozon tabakasının incelmesi ve iklim değişiklikleri gibi önemli bir takım çevresel tehditlerin meydana gelmesine neden olmaktadır. Bu çevresel sorunların üstesinden gelebilmek için işletmeler çevre üzerindeki baskıların fiziksel olarak yönetilmesine odaklanmış ve çevre yönetimi kavramı ortaya çıkmıştır. Çevre yönetimi kavramının önem kazanmaya başlamasıyla da çeşitli işletme kollarında çevresel duyarlılı̆̆ planlama, ölçme, kontrol etme, değerlendirme ve ödüllendirme eğilimleri kapsamında kullanılmak üzere birtakım çevre yönetim sistemi (ÇYS) programları geliştirilmiştir. Bu programlar çeşitli sektörlerde faaliyet gösteren işletme kolları için ortak olabileceği gibi sektöre veya işletme türüne özgü de tasarlanabilmektedir. Ulusal veya küresel düzeyde geçerliliği olan ÇYS'ler için gerekli uygulamaları yerine getiren işletmeler çeşitli şekillerde (mühür, yıldız, plaket, madalya, yaprak vb.) ödüllendirilebilmekte veya sertifikalandırılmaktadır. ÇYS’ler kamu veya özel sektör kurum/kuruluşları veya mesleki birlikler tarafından yürütülebilmektedir. ÇYS'lerin yaygın olduğu alanlardan birisi de turizm ve konaklama sektörüdür. Özellikle otel işletmeleri başta olmak üzere turizm işletmeleri çevreyle olan etkileşiminde oluşan/verilen zararların en aza indirilmesi için çevresel uygulamaları ön plana çıkarmak adına sürdürülebilir kalkınma amaçları kapsamında çevre yönetimi çalışmalarını hızlandırmaktadır. Bu doğrultuda oteller çevre politikaları belirleyerek eylem planları oluşturmakta, çevreyle ilgili uygulamaları benimsemekte ve yürütmekte, çevre performanslarını takip etmekte, çevreye duyarlı ürünler kullanmakta ve çevresel faaliyetleri kontrol altına alabilmek için ÇYS programlarına yönelmektedir (Boyraz, 2017).

Otellerin ÇYS'leri tercih etmesinin ardında birtakım önemli belirleyiciler bulunmaktadır. Bunlar; karar vericiler olarak iç paydaşlar niteliğinde işletme sahipleri, yöneticileri veya çalışanları diş paydaşlar olarak ise işletme üzerinde baskı oluşturan müşteriler, hissedarlar, tedarikçiler, iş ortakları, mesleki örgütlerdir. Bununla birlikte ÇYS'lerin işletmelere sağlayacağı avantajları göz önünde bulundurarak da oteller bu tür programları benimseyebilmektedir. Bu avantajlar arasında; israfların azaltılarak işletme verimliliğinim artırılması (Enz ve Siguaw, 1999; Akdağ vd., 2014), maliyetlerin azaltılması ile karlılığın artırılması (Alexandre ve Kennedy, 2002; Kassinis ve Soteriu, 2003), kurumsal imaja katkı sunarak rekabet üstünlüğü sağlanması (Akatay ve Aslan, 2008; Atay ve Dilek, 2013), çalışan ve misafir bilincinin artırılması (Bohdanowicz, 2006) öncelikli olarak vurgulanmaktadır. Bununla birlikte iç ve dış paydaş baskılarına ve ÇYS'lerin sağladığı katkılara rağmen birçok otel resmi bir ÇYS benimsememektedir. Türkiye'de oteller için yürürlükte olan ÇYS'ler göz önüne alındığında; 2019 yılı Aralık ayı itibariyle uluslararası nitelikli olan Yeşil Anahtarlı otel oranı \%2,80 (www.turcev.org.tr), Travelife sertifikalı otel oranı $\% 2,77$ (www.travelife.info), ulusal nitelikli olarak da Yeşillenen Oteller Belgesi alan otel oranı \%1,76 (www.yesillenenoteller.com) iken Çevreye Duyarlı Konaklama Tesisi (Yeşil Yıldız) Belgesi alan otel oranının \%13,90 (yigm.ktb.gov.tr) düzeyinde kaldığı görülmektedir. En yaygın veya popüler ÇYS'nin bile oteller içerisindeki payının \%15'in altında kalması otellerin neden bu tür resmi bir ÇYS'ne dahil olmadıkları ve ÇYS'leri benimsememelerinin ardındaki engelleyici faktörlerin neler olduğu sorusunu akıllara getirmektedir. Nitekim literatürde yer alan çalışmaların genellikle; otellerde çevre yönetimi ile ilgili hangi tür uygulamaların gerçekleştirildiği (Bohdanowicz, 2006, Boyraz, 2017), ÇYS'nin otellere sağladığı avantajlar (Bellesi vd., 2005; Akdağ vd., 2014) ve otelleri ÇYS'ye yönlendiren motive edici faktörler (Chan ve Wong, 2006; Best ve Thapa, 2013) üzerine yoğunlaştığı göz önüne alındığında oteller için ÇYS'nin ne tür engelleyicilerinin olduğunun ortaya konması daha önemli bir hal almaktadır. Bu amaçla Chan (2008) tarafından uluslararası nitelikli otellerde ÇYS'nin engelleyicilerini belirlemeye yönelik bir ölçek geliştirilmiş ve Hong Kong' daki otellerde bu ölçek test edilmiştir. Türkiye'deki otellerde ÇYS'nin mevcut benimsenme 
oranlarının çok düşük olduğu göz önüne alındığında, ÇYS'nin engelleyicilerini belirlemeye yönelik böyle bir ölçeğin Türkçeye uyarlanması ve kullanılması gerekmektedir. Bu noktadan hareketle, belirtilen amaca yönelik olarak Chan (2008) tarafından geliştirilen ÇYS'nin engelleyici ölçeğinin Türkçeye uyarlanması çalışmanın odak noktasını oluşturmaktadır.

\section{ÇEVRE YÖNETIM SISTEMININ ENGELLEYICILLERI}

Çevre yönetimi, yönetim süreci aşamalarının (planlama, örgütlenme, yürütme, eşgüdümiletişim, kontrol-denetim) çevre koruma ve kullanma dengesinin sağlanması bağlamında yürütülmesidir (Toprak, 2012). Kavram otel işletmeleri açısından; kuruluş ve inşaat aşamasında ekolojik çevrenin karar alma süreçlerinde önemli bir unsur olarak dikkate alınmasını, otel içi faaliyetler esnasında veya sonrasında çevreye verilen zararın en alt seviyeye indirmesi hedeflenen, bu çerçevede, satın alınan ürünlerin tercihinde tasarım ve paketlenmesine dikkat eden, üretim süreçlerinde değişiklikler yapabilen, ekolojik çevrenin korunması felsefesini işletme kültürüne yerleştirmek için çabalayan, sosyal sorumluluk kapsamında topluma karşı görevlerini yerine getirme bilincinin benimsediği anlayışı (Nemli, 2000:17) ifade etmektedir. Çevre yönetim sistemi ise Uluslararası Standardizasyon Örgütü (International Organization for Standardization-ISO) tarafından "bir kuruluşun çevresel yükümlülüklerini yerine getirmek için attığ1 eylemleri planlama, uygulama, gözden geçirme ve iyileştirmenin sürekli döngüsü" olarak tanımlanmaktadır (ISO, 1996). Otel işletmelerinin bu türden bir ÇYS'yi benimsemesi için belirleyici, motive edici, kolaylaştırıcı ve sınırlayıcı unsurlar olabileceği gibi mevcut yürürlükte olan herhangi bir ÇYS'ye yönel(e)memesinin önünde engelleyici faktörler de bulunabilir.

Çevre yönetim sisteminin engelleyicileri; kamu, özel kurum/kuruluşlar veya diğer mesleki ya da sivil örgütler tarafından yürütülen çevre yönetim sistemi, programı ya da ödüllerinden herhangi birisinin otel işletmelerinde benimsenmesini veya uygulanmasını mümkün kılmayan/önleyen sebep veya faktörler bütününü ifade etmektedir. Literatürde faklı sektörlerde faaliyet gösteren işletmelerin ÇYS engelleyicilerini belirlemeye yönelik birçok çalışma gerçekleştirilmiştir. Bunlar arasında; bilgisayar, elektronik ve taşımacılık sektöründe (Quazi, 1999), otomotiv endüstrisinde (Martin-Pena vd., 2014), sağllk sektöründe (Pinzone vd., 2015), yiyecek endüstrisinde (Massoud vd., 2014), kimya, plastik, metal, gıda ve tarım sektörlerinde (Mariotti vd., 2014), sanayi sektöründe (Jabbour vd., 2016), üretim sektöründe (Santos vd., 2016), eğitim alanında üniversitelerde (Levy ve Dilwali, 2000) yapılan araştırmalar örnek gösterilebilir. Bu çalışmalarda genel olarak görüşme tekniği kullanılmış ve işletmelerin ISO 14000 Çevre Yönetim Sistemlerine ilişkin engelleyicileri tespit edilmeye çalışılmıştır. Örneğin; Singapur'daki işletmeler için ISO 14001 Çevre Yönetim Sistemi'nin yedi engelleyicisi olduğu tespit edilmiştir (Quazi, 1999). Bunlar; ISO standartlarının karmaşıklığı, yasal sonuçlar, uygulamaya yönelik teşviklerin eksikliği, yönetim taahhüdünün eksikliği, çalışan katılımının eksikliği, uygulama maliyetinin yüksekliği ve çalışan sorumluluklarının belirsizliğidir. Benzer şekilde Lübnan'daki işletmelerin yine ISO 14001 Çevre Yönetim Sistemini benimsemesinin önünde dokuz engelleyici sebebin olduğu belirlenmiştir (Massoud vd., 2014). Bunlar önem düzeyine göre; zaman talebi, işletme içi bilgi eksikliği, ÇYS'nin yönetim tarafından öncelikli olarak görülmemesi, sertifikasyon maliyeti, ihracat için ÇYS gerekliliği aranmaması, müşteri talebinin olmaması, faydalarının açık olmaması, yasal zorunluluğunun bulunmaması, hükümet desteğinin eksikliği şeklinde sıralanmaktadır. ABD'deki üniversitelerde yapılan çalı̧̧mada ise sürdürülebilir kaynak kullanımında sürdürülebilirliğin dikkate alınamamasında yedi temel engelleyicinin olduğu ortaya konmuştur (Levy ve Dilwali, 2000). Bunlar arasında; etkili koruma önlemleri konusundaki bilgi eksikliği, personel mevcudiyetinin sınırlandırılması, sınırlı sermaye bütçeleri, yeni teknoloji hakkında bilgi 
eksikliği, kurumsal hafıza eksikliği, performans ölçütlerinin eksikliği ve çevresel kazanımları ölçmede zorluk yer almaktadır.

Literatürde yer alan çalışmaların bir bölümü işletmelerdeki ÇYS engelleyicilerini sınıflandırmaya odaklanmıştır. Bu çalışmalarda ÇYS'nin engelleyicileri, sektörel ve örgütsel (Post ve Altman, 1994) ya da dış ve iç (Hillary, 1999; 2004; Shi vd., 2008) engelleyiciler olarak iki gruba ayrılmıştır. Post ve Altman'a (1994) göre sektörel engeller, işletmelerin dâhil olduğu ticari faaliyetin türü ile ilgili sektörden kaynaklanan; sermaye maliyetleri, rekabetçi baskılar, sektörel düzenlemeler, teknik bilgi ve olası sonuçlar hakkındaki belirsizlikler olarak beş faktörden oluşmaktadır. Örgütsel engeller ise, işletmelerin kendi faaliyetlerinden kaynaklanan ve dâhil oldukları iş faaliyetine bakılmaksızın işletmeleri etkileyen; çalışanların tutumu, üst yönetim liderliğinin yetersizliği, zayıf iletişim ve geçmiş uygulamalar şeklinde dört faktörden oluşmaktadır. Hillary $(1999,2004)$ ise ÇYS' nin toplam 48 engelleyicisinin olduğunu tespit etmiş olup diş engelleyicileri, sertifikalandırıcı/onaylayıcı, ekonomik, kurumsal zayıflıklar, destek ve rehberlik başlıklarında; iç engelleyiciler ise kaynaklar, anlayış ve algılama, uygulama, tutum ve örgüt kültürü başlıklarında altında toplanmıştır. Shi vd., (2008) de benzer bir yöntemle işletmelerin temiz üretim yapmamasının engelleyicilerini; dış engelleyiciler (politika ve pazar engelleri, mali ve ekonomik engeller) ve iç engelleyiciler (teknik ve bilgi engelleri, yönetsel ve örgütsel engeller) şeklinde sinıflandırmıştır.

Farklı sektörlerin yanı sıra turizmde de ÇYS'nin engelleyicilerine yönelik birtakım çalışmalar gerçekleştirilmiştir. Bu çalışmalar; Guernsey adası (Stabler ve Goodall, 1997), Danimarka (Bramwell ve Alletrop, 2001), İngiltere'den Plymouth (Hobson ve Essex, 2001) ve Caradon (Vernon vd., 2003), İspanya (Ayuso, 2007), Hong Kong (Chan, 2008), Karayipler (Best ve Thapa, 2013), Malezya (Yusof ve Jamaludin, 2014) ve Tayvan (Mak ve Chang 2019) gibi çeşitli ülke ve destinasyonlarda faaliyet gösteren farklı türdeki konaklama işletmeleri üzerinde gerçekleştirilmiştir. Stabler ve Goodall (1997) sektördeki işletmelerin çevre yönetimini uygulamamasının sekiz engelleyicisinin olduğunu vurgulamaktadır. Bunlar önem sırasına göre; işletme performansının tatmin edici olması, çevre yönetiminin performans üzerinde minimum etkiye sahip olması, sermaye maliyetlerinin yüksekliği, işletme maliyetlerinin yüksekliği, uygulamaları takip etmek için zaman yetersizliği, oteller için önemli olmaması, ticari bir faydasının görülmemesi ve personeli dahil etmedeki zorluklardır. Bramwell ve Alletrop (2001) da turizm endüstrisinde sürdürülebilir eylemlerin benimsenmesinin önünde altı engelleyiciyi faktör olduğunu belirtmektedir. Bunlar; yüksek yatırım maliyetleri, sektörün olumsuz vergi durumu, sektördeki olumsuz tavırlar ve bilgi eksikliği, pratik zorluklar, yerel yöneticilerden sınırlı taahhüt ve kavramı tanımlamanın zorluğu ve çok fazla teorik düzeyde kalması şeklinde sıralanmaktadır. Hobson ve Essex (2001) çevre yönetimi uygulamalarının ilk yatırım maliyeti, zaman ve enerji, misafir muhalefeti, çalışan muhalefeti, işletme operasyonlarındaki dış kısıtlayıcılar, bilgi ve destek eksikliği ile ilgi eksikliği olmak üzere toplam yedi ayrı engelleyicisinin olduğunu ifade etmektedir. Yusof ve Jamaludin (2014) literatürde yer alan ÇYS'nin 12 engelleyicisinden altısının Malezya'daki oteller için geçerli olduğunu ortaya çıkarmıştır. Bu engelleyiciler; uzman eksikliği, kaynak eksikliği (ekipman/işgücü), hizmet kalitesinin çevresel performansla dengelenmesindeki güçlükler, yüksek uygulama maliyeti, hükümet düzenlemelerinin ve uygulamalarının olmaması ve personeli yönetme ve yetiştirmedeki zorluklardır. Ayuso (2007) ise yaptığı çalışmada otellerin çevre yönetimi uygulamalarını yürütürken 11 farklı engelleyiciyle karşılaştıklarını tespit etmiştir.

Turizmle ilgili literatürdeki diğer çalı̧̧malar konaklama işletmelerdeki ÇYS engelleyicilerini gruplandırarak ele almıştır. Örneğin, Vernon vd., (2003) 22 adet engelleyicinin var olduğunu tespit etmiştir. Bunların 11'ini doğrudan işletmenin kendisini ilgilendiren ve diğer 11'ini işletme dışındaki müdahale edilemeyen (altyapısal, ekonomik ve siyasi nitelikli) dolaylı engelleyiciler olarak 
iki başlıkta gruplandırmaktadır. Best ve Thapa (2013) çevre yönetimi uygulamalarının önündeki engelleri; fayda maliyeti engelleri, örgütsel engeller ve teknik engeller şeklinde sınıflandırarak her bir alt engelleyici grubunda dörder faktör tanımlamış ve toplamda konaklama işletmeleri için 12 adet engelleyicinin olduğu belirlemişlerdir. Mak ve Chang (2019) da otel işletmelerinde çevre stratejisinin benimsenmesinin önündeki 13 engelleyicinin var olduğunu ortaya koymuş ve bunların yedisi dış engelleyiciler altısı ise iç engelleyicileri olarak iki başlıkta sınıflandırmıştır.

Literatürde yer alan otel işletmelerine yönelik çevre yönetimi ve ÇYS ile ilgili çalışmalar büyük çoğunlukla doğrudan ÇYS'nin engelleyicilerine odaklanmamış olup çalışmalarda ÇYS'nin engelleyicileri çevre yönetimiyle ilgili uygulama türleri ve en iyi uygulamalar, ÇYS'nin belirleyicileri, motive edici faktörleri, olası çıktıları, avantajları gibi çeşitli konular ele alınmıştır. Mevcut çalışmalarda engelleyicilerin ortaya çıkarılmasında nitel araştırma yöntemlerinden mülakat tekniği veya kavramsal olarak ikincil verilerin derlenmesi şeklinde bir yol benimsenmiş ve herhangi bir ölçek kullanılmamıştır. Dolayısıyla literatürde ÇYS'nin engelleyicilerini belirlemeye yönelik Chan'ın (2008) dişında nicel bir araştırmaya rastlanmamıştır.

Çalışmanın ortaya çıkış noktası olan Chan (2008) araştırmasında, ÇYS'nin benimsenmesi ve uygulanmasının önündeki engellerin ayrıntılı bir listesini oluşturan Hillary'nin (2004) çalışmasını dikkate alarak otel endüstrisinde tamamen ÇYS'nin engelleyicilerine odaklanmış ve Hong Kong' da faaliyet gösteren ISO 14001 belgeli 81 otelde bu engelleyicileri test ederek bir ölçek geliştirmiştir. Bu kapsamda otel işletmelerinde ÇYS'nin 28 ayrı engelleyicisi olduğunu ortaya koyan Chan (2008), bu engelleyicileri dış ve iç engelleyiciler olmak üzere iki gruba ayırmıştır. Altı faktörlü yapıdan oluşan ÇYS engelleyici ölçeğindeki faktörlerin öz değer büyüklüğüne göre sıralı olarak isimleri ile içerdiği madde sayısı aşağıda belirtilmiştir:

1. Faktör: Bilgi ve Beceri Eksikliği - 9 Madde (İç)

2. Faktör: Mesleki Tavsiye Eksikliği - 7 Madde (Dış)

3. Faktör: Sonuçların Belirsizliği - 4 Madde (Dış)

4. Faktör: Sertifika Veren/Doğrulayıcı Kuruluşlar - 3 Madde (Dış)

5. Faktör: Kaynakların Kıtlı̆̆ 1 - 3 Madde (İç)

6. Faktör: Uygulama ve Bakım Maliyetleri - 2 Madde (İç)

Chan (2008) tarafından otel işletmelerinin neden bir ÇYS'ye dâhil olmadığını nitelendirmeye yönelik oluşturulan ÇYS'nin engelleyicileri ölçeği, turizm sektörü nezdinde diğer sektör işletmeleri için de bir ilk niteliğindedir. Bu nedenle ölçeğin farklı ülke ve destinasyonlardaki otel işletmelerinde ÇYS uygulamalarının değerlendirilmesi için de kullanabilir olması önemlidir.

\section{YÖNTEM}

Bu araştırmanın amacı, Chan (2008) tarafından geliştirilen Çevre Yönetimi Sistemi Engelleyicileri (Barriers of Environmental Management Systems) Ölçeğinin Türkçeye uyarlanmasıdır. Beşli Likert tipi (1-Kesinlikle Katılmıyorum, 2-Katılmıyorum, 3-Ne Katıllyorum / Ne Katılmıyorum, 4Katıllyorum, 5-Kesinlikle Katıllyorum) 28 ifadeden oluşan ölçme aracı, iç ve diş engeller olmak üzere altı faktörlü yapıdadır. Ölçeğin uyarlanması sürecinde ilk olarak, dil geçerliliği için uzman eşliğinde orijinal dilinden (İngilizce) Türkçeye çeviri ve geri çeviri (Türkçeden İngilizceye) yapılmıştır. Yapılan çeviriler karşılaştırıldığında uyum oranının \%90'dan fazla olduğu görülmüş ve ifadelerin dil geçerliği açısından herhangi bir anlam karmaşasına yol açmadı̆̆ belirlenmiştir. Böylelikle ölçeğin orijinal dili ile Türkçesi arasındaki anlamsal doğruluk sağlanmıştır (Van de Vijyer and Hambleton, 1996). İkinci olarak ölçeğin kapsam geçerliği için konuyla ilgili uzman görüşleri alınarak öneriler doğrultusunda ölçek ifadelerinde gerekli düzenlemeler gerçekleştirilmiştir (Öksüz ve Malhan, 2005). Böylelikle ölçek ön test (pilot çalışma) uygulaması için uygun hale getirilmiştir. Çalışmanın evreni, Türkiye'de faaliyet gösteren ve herhangi bir çevre yönetim sistemi, programı ya da ödülüne sahip olmayan Kültür ve Turizm Bakanlığı'ndan 
turizm işletme belgeli otel sınıfındaki 2339 (1 Ocak 2021 itibariyle) işletmeyi kapsamaktadır (Kültür ve Turizm Bakanlığı, 2020). Aynı tarih itibariyle Türkiye'de bakanlıktan turizm işletme belgeli otel sınıfında 3114 işletme yer alırken bunların 775'i en az bir kurum veya kuruluştan alınmış çevre belgesi ödülüne sahiptir. Bu doğrultuda 1-14 Şubat 2021 tarihleri arasında öncelikle ön test (pilot çalışma) için 200 otel işletmesinin orta ve üst düzey yöneticisi ile anket uygulaması gerçekleştirilmiştir. Elde edilen verilere madde analizi, güvenirlik analizi, madde toplam korelasyon analizi, KMO ve Barlett analizi ve açıklayıcı faktör analizi (AFA) uygulanmıştır. Pilot çalışma sonucunda açıklanan faktör yapısını farklı bir örneklem grubu ile doğrulanmak amacıyla takip eden aşamada ise 15-28 Şubat 2021 tarihleri arasında ilave 200 otele daha ulaşım sağlanarak toplamda 400 anket uygulanmıştır. Çalışmada elde edilen bu verilerin hepsine ise LISREL 8.7 istatistik programı aracılığıyla doğrulayıcı faktör analizi (DFA) uygulanmıştır. Çalışma, Afyon Kocatepe Üniversitesi Sosyal ve Beşeri Bilimleri Bilimsel Araştırma ve Yayın Etiği Kurulu tarafından 12.10.2020 tarihli ve 2020-163 sayılı kararı ile etik açıdan uygun bulunmuştur.

\section{BULGULAR}

Çalışmada ilk olarak pilot çalışma kapsamında elde edilen veriler doğrultusunda çevre yönetim sistemi engelleyicileri ölçeğine ilişkin madde analizi sonuçlarına Tablo 1'de yer verilmiştir. Ölçekteki her bir maddenin kendisi dişındaki maddelerle olan korelasyon katsayısının 0,30'un altında bir değer almaması beklenmektedir (Büyüköztürk, 2009).

Tablo 1. Çevre Yönetim Sistemi Engelleyicileri Ölçeği'ne İlişkin Madde İstatistikleri

\begin{tabular}{|c|c|c|c|c|}
\hline $\begin{array}{l}\text { Madde } \\
\text { No }\end{array}$ & $\begin{array}{l}\text { Madde Silme Ölçek } \\
\text { Ortalaması }\end{array}$ & $\begin{array}{c}\text { Madde Silme Ölçek } \\
\text { Varyansı }\end{array}$ & $\begin{array}{l}\text { Madde-Ölçek } \\
\text { İlişkisi }\end{array}$ & $\begin{array}{l}\text { Madde Silme Güvenirlik } \\
\text { Değeri }\end{array}$ \\
\hline 1 & 98,050 & 423,827 & 0,909 & 0,942 \\
\hline 2 & 97,930 & 434,387 & 0,697 & 0,944 \\
\hline 3 & 97,935 & 435,136 & 0,672 & 0,944 \\
\hline 4 & 97,935 & 436,332 & 0,663 & 0,945 \\
\hline 5 & 97,960 & 431,807 & 0,711 & 0,944 \\
\hline 6 & 98,000 & 436,734 & 0,662 & 0,945 \\
\hline 7 & 97,970 & 436,683 & 0,663 & 0,945 \\
\hline 8 & 97,895 & 436,275 & 0,662 & 0,945 \\
\hline 9 & 97,940 & 435,544 & 0,674 & 0,944 \\
\hline 10 & 98,005 & 435,794 & 0,670 & 0,945 \\
\hline 11 & 98,080 & 437,119 & 0,600 & 0,945 \\
\hline 12 & 97,975 & 439,974 & 0,555 & 0,946 \\
\hline 13 & 98,020 & 437,919 & 0,571 & 0,945 \\
\hline 14 & 98,110 & 439,204 & 0,562 & 0,946 \\
\hline 15 & 98,015 & 440,618 & 0,503 & 0,946 \\
\hline 16 & 97,990 & 442,814 & 0,476 & 0,946 \\
\hline 17 & 98,435 & 433,724 & 0,739 & 0,944 \\
\hline 18 & 98,225 & 431,592 & 0,640 & 0,945 \\
\hline 19 & 98,305 & 429,690 & 0,672 & 0,944 \\
\hline 20 & 98,210 & 429,654 & 0,679 & 0,944 \\
\hline 21 & 98,495 & 428,945 & 0,599 & 0,945 \\
\hline 22 & 98,390 & 431,998 & 0,534 & 0,946 \\
\hline 23 & 98,385 & 430,640 & 0,562 & 0,946 \\
\hline 24 & 98,525 & 434,904 & 0,489 & 0,947 \\
\hline 25 & 98,390 & 432,108 & 0,535 & 0,946 \\
\hline 26 & 98,370 & 430,676 & 0,546 & 0,946 \\
\hline 27 & 98,715 & 444,165 & 0,497 & 0,946 \\
\hline 28 & 98,480 & 437,809 & 0,536 & 0,946 \\
\hline \multicolumn{5}{|c|}{ Cronbach's Alpha $(\alpha)=0,947$} \\
\hline
\end{tabular}


Tablo 1 incelendiğinde, ölçekteki her maddenin diğer maddelerle olan ilişki değerinin 0,30'un altında olmadığı görülmektedir. Böylelikle ölçekten madde çıkarılmasına gerek olmadığına karar verilmiştir. Ölçeğin iç tutarlılığını belirlemek için yapılan güvenirlik analizi ile Cronbach's Alpha $(\alpha)$ katsayısının 0,947 olduğu tespit edilmiştir. Bu sonuç ölçeğin güvenirlik düzeyinin $0.80 \leq \alpha<$ 1.00 arasında yer alarak yüksek olduğunu göstermektedir (Lorcu, 2015:208).

Çalışmada ikinci olarak ölçeğinin maddeleri ile ölçek toplam korelasyonu değerleri incelenmiş ve elde edilen bulgulara Tablo 2'de yer verilmiştir. Tablo 2'ye göre madde-toplam ilişki değeri tüm maddeler için 0,30'un üzerindedir. Dolayısıyla maddelerin ölçme gücü yeterli seviyededir (Altunışık vd., 2002:271). Her bir madde ile ölçekteki toplam madde değeri arasındaki ilişki katsayısı 0,516-0,917 arasında değiştiği görülmektedir. Bununla birlikte ölçek maddeleri ile ölçek toplamı arasındaki ilişkilerin istatistiki açıdan anlamlı olduğu belirlenmiştir $(\mathrm{p}<0.01)$. Bu durum maddelerin birbirleriyle olan tutarlılığında herhangi bir problem olmadığını göstermektedir.

Tablo 2. Ölçek Maddeleri İle Ölçek Toplam Korelasyonu Değerleri

\begin{tabular}{cccccc}
\hline Madde No & $\mathrm{r}$ & $\mathrm{p}$ & Madde No & $\mathrm{r}$ & $\mathrm{p}$ \\
\hline 1 & 0,917 & $0,000^{* *}$ & 15 & 0,543 & $0,000^{* *}$ \\
\hline 2 & 0,722 & $0,000^{* *}$ & 16 & 0,516 & $0,000^{* *}$ \\
\hline 3 & 0,699 & $0,000^{* *}$ & 17 & 0,760 & $0,000^{* *}$ \\
\hline 4 & 0,690 & $0,000^{* *}$ & 18 & 0,674 & $0,000^{* *}$ \\
\hline 5 & 0,736 & $0,000^{* *}$ & 19 & 0,704 & $0,000^{* *}$ \\
\hline 6 & 0,689 & $0,000^{* *}$ & 20 & 0,710 & $0,000^{* *}$ \\
\hline 7 & 0,690 & $0,000^{* *}$ & 21 & 0,641 & $0,000^{* *}$ \\
\hline 8 & 0,689 & $0,000^{* *}$ & 22 & 0,582 & $0,000^{* *}$ \\
\hline 9 & 0,700 & $0,000^{* *}$ & 23 & 0,607 & $0,000^{* *}$ \\
\hline 10 & 0,697 & $0,000^{* *}$ & 24 & 0,540 & $0,000^{* *}$ \\
\hline 11 & 0,633 & $0,000^{* *}$ & 25 & 0,583 & $0,000^{* *}$ \\
\hline 12 & 0,589 & $0,000^{* *}$ & 26 & 0,594 & $0,000^{* *}$ \\
\hline 13 & 0,606 & $0,000^{* *}$ & 27 & 0,532 & $0,000^{* *}$ \\
\hline 14 & 0,596 & $0,000^{* *}$ & 28 & 0,576 & $0,000^{* *}$ \\
\hline
\end{tabular}

${ }^{* *} \mathrm{p}<0.01$

Üçüncü olarak pilot çalışma kapsamında ölçeğin geçerliliği için açıklayıcı faktör analizi yapılmıştır. Bu analizin ön koşulları olan veri yapısının faktör analizi yapılabilmesi için yeterliliğine karar vermek ve değişkenler arasındaki ilişkinin varlığı ortaya koyabilmek amacıyla KMO ve Barlett Küresellik Testleri uygulanmıştır (Tabachnick ve Fidell, 2013). KMO ölçümleri 01 arasında değer almakta olup bu değerin, 1'e doğru yaklaşması verilerin faktör analizine olan uygunluğunu işaret etmekte ve 0,80'den daha fazla olması önerilmektedir (Alpar, 2011:286; Kaiser, 1974). Çalışmanın KMO ve Barlett Küresellik Test sonuçları Tablo 3'te verilmiştir. Tablo 3'e göre KMO değerinin 0,927 çıtığı ve Barlett Küresellik Testinin ise istatistiksel olarak \%99 güven düzeyinde anlamlı bulunduğu $(\mathrm{p}<0.01)$ görülmektedir. Elde edilen bu sonuçlar pilot çalışmadaki örneklem sayısının faktör analizine uygunluğunun yeterli düzeyde olduğu ve verilerin istatistiki olarak çok değişkenli normal dağılımdan geldiğini göstermektedir (Kan ve Akbaş, 2005). Dolayısıyla açıklayıcı faktör analizi için gerekli tüm ön koşullar sağlanmış durumdadir.

Dördüncü adımda ölçeğe ilişkin açıklayıcı faktör analizi yapılmış ve elde edilen bulgulara Tablo $4^{\prime}$ te yer verilmiştir. Faktör analizinde öz değeri 1'den büyük olan faktörler anlamlı kabul edilmektedir. Bu nedenle 1'den küçük öz değeri olan faktörler dikkate alınmamaktadır (Kalaycı, 2017:322). Tablo 4 incelendiğinde, çevre yönetim sistemi engelleyicileri ölçeğinin öz değeri 1'in 
üzerinde altı faktörlü bir yapıdan oluştuğu görülmektedir. Ölçeğin birden fazla faktörlü yapıda olması nedeniyle temel bileşenler analizlerinden varimax rotasyon (dik döndürme) tekniği uygulanmiştır.

Tablo 3. Ölçeğe Ait KMO ve Barlett Analizi Sonucu

\begin{tabular}{lcc}
\hline Kaiser-Meyer-Olkin (KMO) Measure of Sampling Adequacy & 0,927 \\
\hline \multirow{3}{*}{ Bartlett's Test of Sphericity } & Ki-kareDeğeri $(\chi 2)$ & 5462,443 \\
\cline { 2 - 3 } & SerbestlikDerecesi $(\mathrm{df})$ & 378 \\
\cline { 2 - 3 } & Anlamllık Değeri $(\mathrm{p})$ & 0,000 \\
\hline
\end{tabular}

Tablo 4. Ölçeğin Öz Değerleri ve Açıkladıkları Varyans Düzeyleri

\begin{tabular}{ccccccc}
\hline \multirow{2}{*}{ Faktörler } & \multicolumn{3}{c}{ Başlangıç Öz Değerleri } & \multicolumn{3}{c}{ Yüklerin Kareler Toplamı } \\
\cline { 2 - 7 } & Toplam & Varyans \% & Kümülatif \% & Toplam & Varyans \% & Kümülatif \% \\
\hline $\mathbf{1}$ & 12,131 & 43,326 & 43,326 & 6,325 & 22,588 & 22,588 \\
$\mathbf{2}$ & 3,769 & 13,461 & 56,787 & 5,503 & 19,652 & 42,241 \\
$\mathbf{3}$ & 2,098 & 7,493 & 64,280 & 3,241 & 11,575 & 53,816 \\
$\mathbf{4}$ & 1,871 & 6,684 & 70,964 & 2,925 & 10,448 & 64,264 \\
$\mathbf{5}$ & 1,662 & 5,934 & 76,898 & 2,867 & 10,241 & 74,505 \\
$\mathbf{6}$ & 1,122 & 4,007 & 80,906 & 1,792 & 6,401 & 80,906 \\
\hline
\end{tabular}

Faktör yapısına daha doğru karar verebilmek için çalışmada ayrıca çizgi yamaç (Scree Plot Test) grafiği incelenmiş ve elde edilen grafiğe Şekil 1'de yer verilmiştir. Şekil 1 değerlendirildiğinde grafikte kırılmanın altıncı boyuttan sonra gerçekleşmeye başladığı ve bu nedenle altıncı boyuttan sonra eğimin diğer faktörler için durağanlaştı̆̆1 görülmektedir. Böylelikle ölçeğin altı faktörlü yapıda olduğu daha belirginleşmiştir.

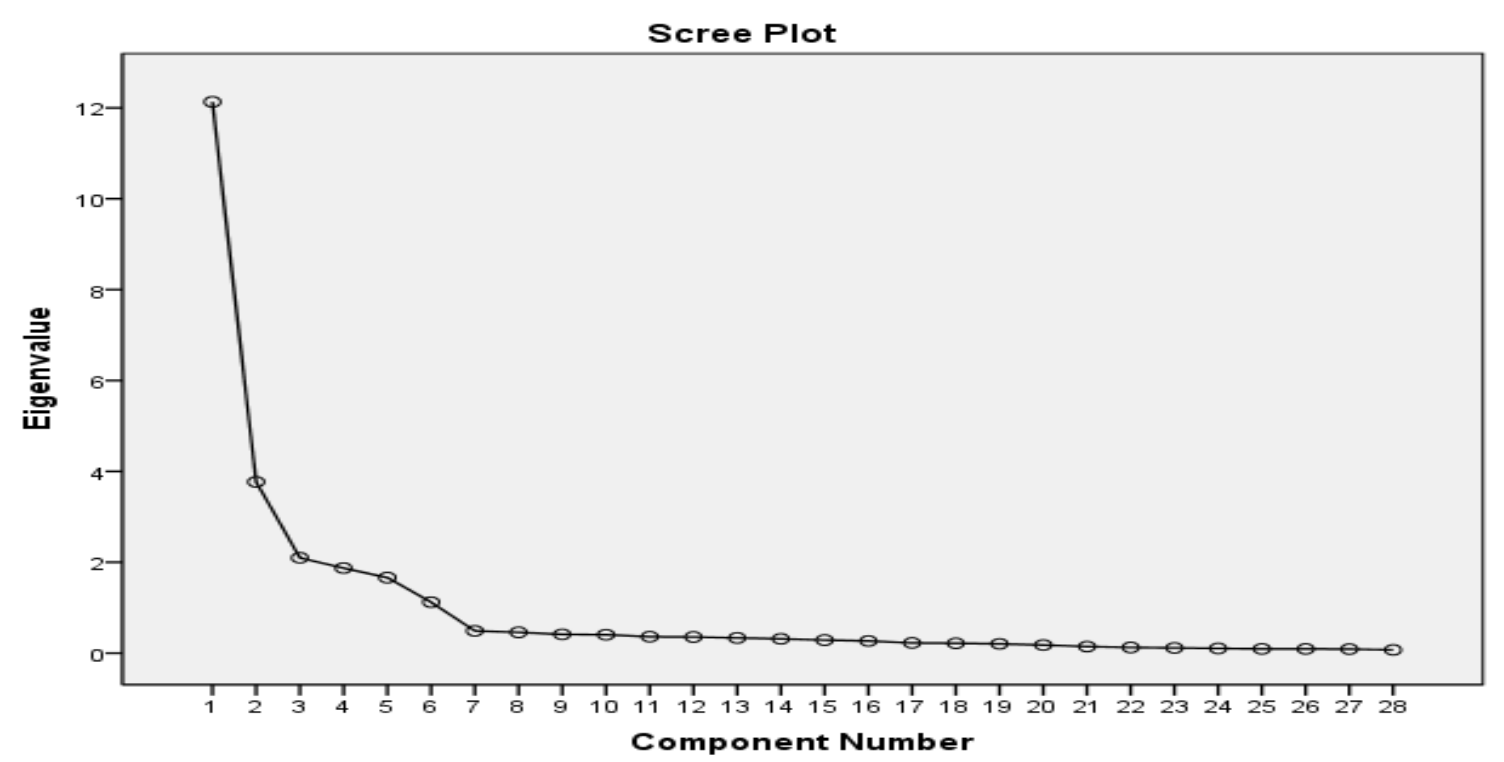

Şekil 1. Ölçeğe Ait Yamaç Grafiği

Ölçekteki faktörlerin sahip olduğu öz değer ile tek başına ölçeğin ne kadarını açıkladıklarına dair oranlar önem düzeyine göre karşılaştırıldığında (Tablo 4); birinci faktörün 12,131 öz değer ile ölçeğin \%22,588'ini, ikinci faktörün 3,769 öz değer ile ölçeğin \%19,652'sini ve üçüncü faktörün 2,098 öz değer ile ölçeğin \%11,575' ini, dördüncü faktörün 1,871 öz değer ile ölçeğin \%10,448'ini, beşinci faktörün 1,662 öz değer ile ölçeğin \%10,241'ini ve altıncı faktörün 1,122 öz değer ile ölçeğin \%6,401'ini açıkladığı tespit edilmiştir. Bu altı faktörün tamamının ise ölçeğin \%80,906'sını 
açıkladığı belirlenmiştir. Elde edilen bu sonuç, Scherer vd., (1988) göre \%40-60 arası, Hair vd., (1998) göre \%60 ve üzeri, Habing (2005) göre \%50 ve üzeri düzeyde belirlenen olması gereken açıllanan varyans değerlerine göre çok iyi düzeydedir.

Tablo 5. Çevre Yönetim Sistemi Engelleyicileri Ölçeği Maddelerine Ait Faktör Yük Değerleri

\begin{tabular}{|c|c|c|c|c|c|c|c|}
\hline \multirow[b]{2}{*}{ Maddeler } & \multicolumn{6}{|c|}{ Faktörler } & \multirow{2}{*}{ Güvenirlik } \\
\hline & 1 & 2 & 3 & 4 & 5 & 6 & \\
\hline 3.Sektöre özgü uygulama araçlarının ve örneklerin eksikliği & 0,796 & & & & & & \\
\hline 5.ÇYS için uzman personelimizin olmaması & 0,785 & & & & & & \\
\hline 4.ÇYS için yeterli teknik bilgi ve becerimizin olmaması & 0,774 & & & & & & \\
\hline $\begin{array}{l}\text { 9.ÇYS için kalitesiz (zayıf) bilgi verilmesi ve çelişkili } \\
\text { yönlendirmelerin yapılması }\end{array}$ & 0,771 & & & & & & \\
\hline $\begin{array}{l}\text { 7.Kavramların yeterince açık olmaması, çevresel yönler ve } \\
\text { önem için daha fazla rehberliğe ihtiyaç duyulması }\end{array}$ & 0,769 & & & & & & 0,946 \\
\hline 2.ÇYS için yeterli tanıtımların yapılmaması & 0,755 & & & & & & \\
\hline $\begin{array}{l}\text { 8.Tecrübeli ÇYS yürütücü/doğrulayıcı kurumların eksik } \\
\text { olması }\end{array}$ & 0,747 & & & & & & \\
\hline 6.ÇYS kriterlerinin ya da değerinin anlaşılır olmaması & 0,746 & & & & & & \\
\hline 1.Çevre yönetim sistemleri (ÇYS) hakkında bilgi sahibi değiliz & 0,699 & & & & & & \\
\hline $\begin{array}{l}\text { 10.ÇYS değerlendirmesi yapan tek bir yetkili kurumun } \\
\text { olmaması }\end{array}$ & & 0,871 & & & & & \\
\hline $\begin{array}{l}\text { 16.Otellere yardımcı olacak deneyimli kalite danışmanlarının } \\
\text { eksikliği }\end{array}$ & & 0,870 & & & & & \\
\hline $\begin{array}{l}\text { 15.Ekonomik iklimin değişmesiyle oteldeki ÇYS'lere verilen } \\
\text { önceliğin değişmesi }\end{array}$ & & 0,851 & & & & & 0,932 \\
\hline 12.Açık belirlenmiş ya da katı bir yasal çerçevenin olmaması & & 0,834 & & & & & \\
\hline $\begin{array}{l}\text { 11.Çevre mevzuatı hakkında merkezi bir bilgi kaynağının } \\
\text { olmaması }\end{array}$ & & 0,815 & & & & & \\
\hline 14.Motive edici faktörlerin ve avantajlarının yetersiz olması & & 0,814 & & & & & \\
\hline 13.ÇYS için kurumsal düzenlemenin yetersiz olması & & 0,812 & & & & & \\
\hline $\begin{array}{l}\text { 18.İ̧sletme hedeflerine ulaşmada ÇYS'nin etkinliğinden kuşku } \\
\text { duymamız }\end{array}$ & & & 0,805 & & & & \\
\hline $\begin{array}{l}\text { 17.Çok yönlü çalışan personelin ÇYS ile dikkatinin kolayca } \\
\text { dağıllabilmesi }\end{array}$ & & & 0,802 & & & & 0027 \\
\hline $\begin{array}{l}\text { 19.ÇYS'nin uygulanması sırasında çevresel yönlerin/etkilerin } \\
\text { değerlendirilmesinde ve öneminin belirlenmesinde zorluk } \\
\text { çekmemiz }\end{array}$ & & & 0,798 & & & & 0,931 \\
\hline 20.ÇYS uygulamanın hiçbir faydasının olmaması & & & 0,793 & & & & \\
\hline $\begin{array}{l}\text { 24.ÇYS uygulamaları ve bakımlar için yöneticilerin veya } \\
\text { personelin zamanının olmaması }\end{array}$ & & & & 0,922 & & & \\
\hline 25.ÇYS için ayırabilecek finansal desteklerin eksikliği & & & & 0,916 & & & 0,958 \\
\hline $\begin{array}{l}\text { 26.ÇYS uygulanması için üst yönetimden gelen desteğin } \\
\text { tutarsız olması }\end{array}$ & & & & 0,903 & & & \\
\hline $\begin{array}{l}\text { 22.Belgelendirme kuruluşlarının sertifikalandırma sürecinin } \\
\text { değişkenlik göstermesi }\end{array}$ & & & & & 0,909 & & \\
\hline $\begin{array}{l}\text { 23.ÇYS'nin turizm pazarındaki değeri konusunda } \\
\text { endişelerimizin olması }\end{array}$ & & & & & 0,906 & & 0,957 \\
\hline 21.Sertifikalandırma/doğrulama maliyetlerinin yüksek olması & & & & & 0,882 & & \\
\hline 27.ÇYS uygulamanın sermaye harcaması gerektirmesi & & & & & & 0,873 & 0,922 \\
\hline 28.Uygulama ve bakım maliyetlerinin yüksek olması & & & & & & 0,864 & 0,922 \\
\hline
\end{tabular}

Ölçek maddelerine ait faktör yük değerleri ile faktörlerin güvenirlik katsayılarına ilişkin bulgulara Tablo 5'de yer verilmiştir. Ölçekten bir maddenin kalmasına karar vermek için faktör yükünün 0,30'un (Yaşlığlu, 2017), 0,40'ın (Kozak, 2015), 0,45'in (Büyüköztürk, 2009), 0,50'nin Hair vd., (1998) üzerinde bir değer olması ve faktörler arasındaki uzaklığın ise 0,10'ın altında olmaması gerekmektedir. Tablo 5'teki analiz sonuçlarına göre, maddelerin faktör yük 
değerlerinin 0,699 ile 0,922 arasında değişkenlik gösterdiği görülmektedir. Faktörlerin güvenirlik katsayılarının ise 0,922 ile 0,958 arasında bir değer aldığı ve güvenirlik düzeylerinin çok yüksek olduğu belirlenmiştir. Ölçekteki faktörler sırasıyla; "Bilgi ve Beceri Eksikliği" (1. Faktör, 1.-9. Maddeler), "Mesleki Tavsiye Eksikliği" (2. Faktör, 10.-16. Maddeler), "Sonuçların Belirsizliği" (3. Faktör, 17.-20. Maddeler), “Kaynakların Kıtlı̆̆ı" (4. Faktör, 21.-23. Maddeler), "Sertifika Veren/Doğrulayıcı Kuruluşlar" (5. Faktör, 24.-26. Maddeler) ve "Uygulama ve Bakım Maliyetleri" (6. Faktör - 27.-28. Maddeler) şeklinde isimlendirilmiştir.

Pilot çalışmanın son olarak beşinci adımında alt ve üst grupların ortalama farkına göre madde analizi gerçekleştirilmiştir. Katılımcıların \%27'lik alt ve üst gruplarının belirlenmesi için ölçekten elde edilen toplam puanlar küçükten büyüğe sıralanmıştır. Sıralanan toplam puanların \%27'lik kısmına gelen en düşük ilk 54 kişi "1" olarak kodlanarak alt gruba atanmış ve en yüksek ilk 54 kişi ise "2" olarak kodlanmış ve üst gruba atanarak değerleri incelenmiştir. Elde edilen bulgulara Tablo $6^{\prime}$ da yer verilmiştir. Tablo 6'ya göre, maddelerin ayırt ediciliğinin kararının verilmesinde kullanılan \%27 alt ve üst değerlerinin tüm maddeler için anlamlı olduğu belirlenmiştir $(p<0.01)$. Bu durum ölçekteki maddelerin kişileri ayırt etmede yeterli olduğunu göstermektedir.

Tablo 6. Ölçek Maddeleri Ayırt Ediciliğinin \%27'lik Alt ve Üst Gruplara Göre Test Edilmesi

\begin{tabular}{cccccc}
\hline Madde No & $\mathrm{t}$ & $\mathrm{p}$ & Madde No & $\mathrm{t}$ & $\mathrm{p}$ \\
\hline 1 & $-16,298$ & $0,000^{* *}$ & 15 & $-7,852$ & $0,000^{* *}$ \\
\hline 2 & $-11,356$ & $0,000^{* *}$ & 16 & $-8,426$ & $0,000^{* *}$ \\
\hline 3 & $-11,841$ & $0,000^{* *}$ & 17 & $-12,351$ & $0,000^{* *}$ \\
\hline 4 & $-11,320$ & $0,000^{* *}$ & 18 & $-10,764$ & $0,000^{* *}$ \\
\hline 5 & $-12,731$ & $0,000^{* *}$ & 19 & $-11,576$ & $0,000^{* *}$ \\
\hline 6 & $-10,765$ & $0,000^{* *}$ & 20 & $-12,139$ & $0,000^{* *}$ \\
\hline 7 & $-11,321$ & $0,000^{* *}$ & 21 & $-9,901$ & $0,000^{* *}$ \\
\hline 8 & $-11,677$ & $0,000^{* *}$ & 22 & $-9,401$ & $0,000^{* *}$ \\
\hline 9 & $-11,311$ & $0,000^{* *}$ & 23 & $-9,855$ & $0,000^{* *}$ \\
\hline 10 & $-10,366$ & $0,000^{* *}$ & 24 & $-9,761$ & $0,000^{* *}$ \\
\hline 11 & $-8,908$ & $0,000^{* *}$ & 25 & $-9,442$ & $0,000^{* *}$ \\
\hline 12 & $-7,691$ & $0,000^{* *}$ & 26 & $-9,781$ & $0,000^{* *}$ \\
\hline 13 & $-8,872$ & $0,000^{* *}$ & 27 & $-8,451$ & $0,000^{* *}$ \\
\hline 14 & $-8,645$ & $0,000^{* *}$ & 28 & $-9,490$ & $0,000^{* *}$ \\
\hline
\end{tabular}

${ }^{* *} \mathrm{p}<0.01$

Çalışmanın ikinci kısmında, pilot çalışma ile açıklanan faktör yapısını tekrar test etmek amacıyla farklı bir örneklemden elde edilen verilere doğrulayıcı faktör analizi (DFA) yapılmıştır. DFA analizine ait standardize edilmiş beta kat sayıları ile path (yol) diyagramı Şekil 2'de verilmiştir. Şekil 2 incelendiğinde, ölçekteki maddelerin faktör yüklerinin 0,77 ile 0,97 arasında bir değer aldığı belirlenmiştir. Bu değerler kabul edilebilir düzeyde olup path diyagramındaki, uyum kriterleri istenilen düzeyde çıtı̆̆ından maddeler arasında herhangi bir modifikasyon yapılmasına ihtiyaç duyulmamıştır. 


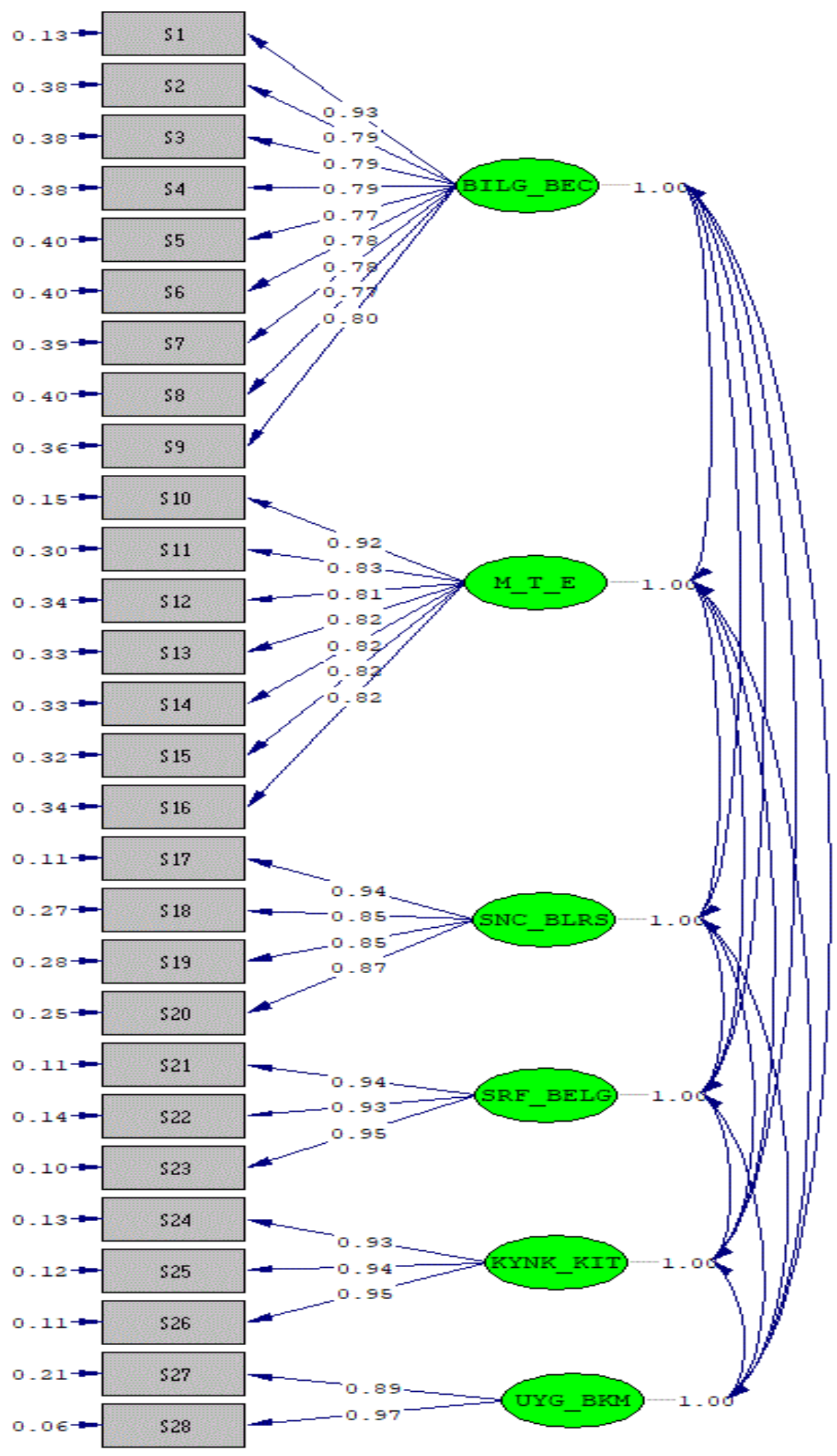

Chi-Square=584.46, df=335, P-value=0.00000, RMSEA=0.043

Şekil 2. Çevre Yönetim Sistemleri Engelleyicileri Ölçeğinin DFA Sonucuna Ait Path Diyagramı Not: BILG_BEC: Bilgi ve Beceri Eksikliği, M_T_E: Mesleki Tavsiye Eksikliği, SNC_BLRS: Sonuçların Belirsizliği, SRF_BELG: Sertifikalandırıcı/Doğrulayıcı, KYNK_KIT: Kaynakların Kıtlığı, UYG_BKM: Uygulama ve Bakım Maliyeti 
Ölçeğe ilişkin DFA modeline ait $t$ değerleri ise Şekil 3 'de verilmiştir. Maddeler ile örtük değişkenler arasındaki ilişkilerden söz edebilmek için $t$ değerleri incelendiğinde, tüm maddeler ile örtük değişkenler arasındaki ilişkinin istatistiki açıdan \%99 güven düzeyinde anlamlı olduğu belirlenmiştir $(t>2,58)$.

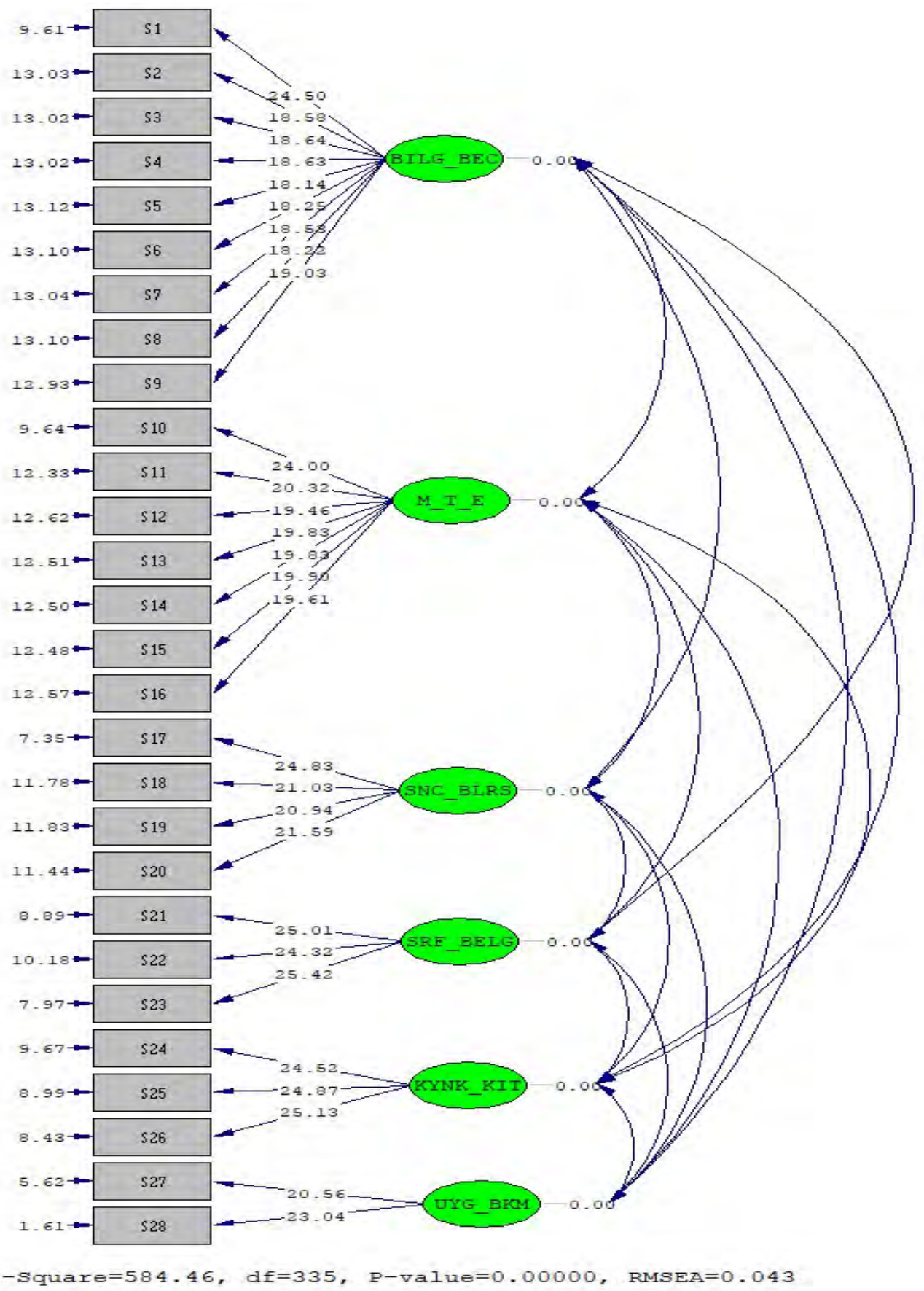

Şekil 3. Çevre Yönetim Sistemleri Engelleyicileri Ölçeğinin DFA Sonucuna Ait t Değerleri

Modelin kabul edilme durumuna karar verebilmek için uyum kriterlerine bakılmaktadır. Schermelleh-Engel vd., (2003) tarafından belirtilen kabul edilebilir ve mükemmel uyum kriterleri Tablo 7'de verilmiştir. 
Tablo 7. Araştırma Kapsamında İncelenen Uyum Kriterleri Sınırlılıkları

\begin{tabular}{ccc}
\hline Uyum Kriterleri & Mükemmel Uyum & Kabul Edilebilir Uyum \\
\hline$\chi 2 / \mathrm{df}$ & $\leq 3$ & $\leq 5$ \\
\hline RMSEA & $0<$ RMSEA $<0.05$ & $0.05 \leq \mathrm{RMSEA} \leq 0.10$ \\
\hline RMR & $0 \leq \mathrm{SRMR}<0.05$ & $0.05 \leq \mathrm{SRMR} \leq 0.10$ \\
\hline SRMR & $0 \leq \mathrm{SRMR}<0.05$ & $0.05 \leq \mathrm{SRMR} \leq 0.10$ \\
\hline NFI & $0.95 \leq \mathrm{NFI} \leq 1$ & $0.90 \leq \mathrm{NFI} \leq 0.95$ \\
\hline NNFI & $0.95 \leq \mathrm{NNFI} \leq 1$ & $0.90 \leq \mathrm{NNFI} \leq 0.95$ \\
\hline CFI & $0.95 \leq \mathrm{CFI} \leq 1$ & $0.90 \leq \mathrm{CFI} \leq 0.95$ \\
\hline GFI & $0.95 \leq \mathrm{GFI} \leq 1$ & $0.90 \leq \mathrm{GFI} \leq 0.95$ \\
\hline AGFI & $0.90 \leq \mathrm{AGFI} \leq 1$ & $0.85 \leq \mathrm{AGFI} \leq 0.90$
\end{tabular}

Kaynak: Schermelleh-Engel vd., (2003)

Ölçeğin DFA sonucunda elde edilen uyum indeksi kriterleri Tablo 8' de verilmiştir. Ölçeğin kabul görmesi için elde edilen uyum iyiliği kriterlerinin en az kabul edilebilir sınırlar arasında olması gerekmektedir. Tablo 8 incelendiğinde; en önemli uyum değeri olan $\mathrm{X}^{2} / \mathrm{df}$ oranının 1,745 ile mükemmel uyum düzeyinde, RMSEA değerinin ise 0,043 ile benzer şekilde mükemmel uyum düzeyinde olduğu görülmektedir. Bunların yanı sıra diğer uyum değerlerinin de mükemmel veya kabul edilebilir uyum değerleri aralığında yer aldığı tespit edilmiştir.

Tablo 8. Çevre Yönetim Sistemi Engelleyicileri Ölçeği Uyum Kriterleri Bulguları

\begin{tabular}{cccccccccc}
\hline $\mathbf{X}^{2} / \mathbf{d f}$ & $\mathbf{p}$ & $\mathbf{R M S E A}$ & $\mathbf{C F I}$ & $\mathbf{G F I}$ & AGFI & NNFI & NFI & RMR & SRMR \\
\hline 1,745 & 0,000 & 0,043 & 0,99 & 0,91 & 0,89 & 0,99 & 0,98 & 0,053 & 0,039 \\
\hline
\end{tabular}

Yapılan tüm analizler ve elde edilen bulgular ÇYSE ölçeğinin Türkçeye uyarlanması için tüm uygun koşulların sağlandığını göstermektedir. Bu kapsamda ÇYSE ölçeğinde 14'ü dış engelleyici ve 14 'ü de iç engelleyici olmak üzere toplam 28 ifadenin yer aldığı doğrulanmıştır. Dış engelleyiciler mesleki tavsiye eksikliği, sonuçların belirsizliği ve sertifika veren/doğrulayıcı kuruluşlar isimli üç faktörden oluşmaktadır. İç engelleyiciler ise yine benzer şekilde bilgi ve beceri eksikliği, kaynakların kıtlı̆̆1 ile uygulama ve bakım maliyetleri olarak üç faktörlü yapıdadır.

\section{SONUÇ}

Çevre Yönetimi Sistemi Engelleyicileri/ÇYSE (Barriers of Environmental Management Systems) Ölçeğinin (Chan, 2008) Türkçeye uyarlanması amacıyla gerçekleştirilen bu çalışmada yapılan geçerlik ve güvenirlik analizleri sonucunda ölçeğin orijinal dilindeki yapısı doğrulanmış ve orijinaline paralel şekilde altı faktörlü yapısının olduğu ortaya konmuştur. Dil ve kapsam geçerliği sağlanan ÇYSE ölçeği, Türkiye'de faaliyet gösteren ve herhangi bir çevre yönetim sistemi, programı ya da ödülüne sahip olmayan turizm işletme belgeli otel işletmelerinin orta ve üst düzey yöneticilerinden oluşan iki ayrı örneklem grubu üzerinde test edilmiştir. İlk aşamada ön test (pilot çalışma) kapsamında 200 otel yöneticisi ile gerçekleştirilen anket uygulaması sonrasında yapılan madde ve korelasyon analizinde tüm ifadelerin ilişki değerlerinin 0,30'un üzerinde yer aldığı, ölçeğin güvenirlik açısından Cronbach's Alpha $(\alpha)$ katsayısının 0,947 ve KMO değerinin 0,927 ile yüksek olduğu, Barlett Küresellik Testinin ise istatistiksel olarak \%99 güven düzeyinde anlamlı bulunduğu $(\mathrm{p}<0.01)$ tespit edilmiştir. Açıklayıcı faktör analiziyle (AFA) de 28 maddeli ölçeğin altı faktörlü yapıda olduğu ve bu faktörlerin ÇYSE ölçeğini açıklama oranının \%80'den fazla olduğu ortaya konmuştur. Bununla birlikte faktör yük değerlerinin 0,699 ile 0,922; güvenirlik katsayılarının ise 0,922 ile 0,958 arasında bir değer aldığı ve güvenirlik 
düzeylerinin çok yüksek olduğu belirlenmiştir. İkinci aşamada ise 400 otel yöneticisi ile gerçekleştirilen anket uygulaması ile pilot çalışma sonucunda açıklanan faktör yapısını doğrulamak amacıyla LISREL 8.7 istatistik programı aracılığıyla doğrulayıcı faktör analizi (DFA) uygulanmıştır. DFA modelindeki standardize edilmiş beta kat sayıları ile path diyagramına göre ölçekteki maddelerin faktör yüklerinin 0,77 ile 0,97 arasında bir değer aldığı ve uyum kriterlerinin istenilen düzeyde olduğu saptanmıştır. Bununla birlikte DFA modelindeki $t$ değerleri incelenmiş ve tüm maddeler ile örtük değişkenler arasındaki ilişkinin istatistiki açıdan $\% 99$ güven düzeyinde anlamlı olduğu belirlenmiştir $(t>2,58)$. Uyum değeri bakımından ise ölçeğe ilişkin X²/df oranının 1,745 ile RMSEA $(0,043)$, CFI $(0,99)$, NNFI $(0,99)$, NFI $(0,98)$ ve SRMR $(0,039)$ değerlerinin mükemmel uyum düzeyinde olduğu tespit edilmiştir. Böylelikle ÇYSE ölçeği için ilk aşamada açılanan faktör yapısı ikinci aşamada da doğrulanmış ve ölçek Türkçeye başarıyla uyarlanmıştır. ÇYSE ölçeği beşli Likert tipi (1-Kesinlikle Katılmıyorum, 2-Katılmıyorum, 3-Ne Katıllyorum / Ne Katılmıyorum, 4-Katılıyorum, 5-Kesinlikle Katılıyorum) 28 ifadeden oluşmaktadır. ÇYSE ölçeğindeki bu 28 ifadenin 14'ü dış engelleyicilere ve 14'ü ise iç engelleyicilere aittir. Altı faktörlü yapıdaki ölçek faktörleri sırasıyla; "1-Bilgi ve Beceri Eksikliği" (9 Madde), "2-Mesleki Tavsiye Eksikliği” (7 Madde), "3-Sonuçların Belirsizliği” (4 Madde), "4-Kaynakların Kıtlığı" (3. Madde), "5-Sertifika Veren/Doğrulayıcı Kuruluşlar" (3. Madde) ve "6-Uygulama ve Bakım Maliyetleri" (2 Madde) şeklindedir.

Son olarak, yapılan tüm analizlerin yanı sıra çalışmanın örneklem büyüklüğü açısından ölçekte yer alan madde sayısının 14 katından fazlasını oluşturan otel yöneticisi üzerinde gerçekleştirilmiş olması, örneklem grubunun yeterli sayıda olduğunu göstermektedir. Nitekim literatürde yer alan faktör analizi yapılabilmesi için gerekli örneklem sayısı büyüklükleri (Preacher and MacCallum'a (2002) göre 3-10 katı, Tavşancıl'a (2002) göre en az 5-10 katı, Kozak'a (2015) göre ölçekteki madde sayısının en az beş katı) ile karşılaştırıldığında çalışmada ulaşılan 400 kişilik örneklem grubu beklentileri karşılamaktadır. Bu noktadan hareketle, Türkçeye uyarlanan ÇYSE ölçeğinin ileride yapılacak otel işletmelerinde çevre yönetimi sisteminin/uygulamalarının engelleyicilerini belirlemeye yönelik araştırmalarda kullanılabilecek geçerli ve güvenilir bir nitelik taşıdığı düşünülmektedir.

\section{KAYNAKÇA}

Akatay, A. ve Aslan, Ş. (2008). Yeşil Yönetim ve İşletmeleri ISO 14001 Sertifikası Almaya Yönelten Faktörler, Dokuz Eylül Üniversitesi Sosyal Bilimler Enstitüsü Dergisi, 10(1): 313-339.

Akdağ, G., Güler, O., Demirtaş, O., Dalgıç, A. ve Yeşilyurt, C. (2014). Turizm ve Çevre İlişkisi: Türkiye'deki Yeşil Otellerin Gözünden Yeşil Otelcilik Uygulamaları Üzerine Bir Değerlendirme. Coğrafyacılar Derneğgi Uluslararası Kongresi, Muğla Sıtkı Koçman Üniversitesi, Muğla 4-6 Haziran 2014, 258-267.

Alexandre, S. and Kennedy, C. (2002). Green Hotels: Opportunities and Resources for Success. Zero Waste Alliance, Portland: One World Trade Center.

Alpar, R. (2011). Uygulamalı Çok Değişkenli İstatistiksel Yöntemler. (3. Baskı). Ankara: Detay Yayıncilik.

Altunışık, R., Coşkun, R., Bayraktaroğlu, S. ve Yıldırım, E. (2012). Sosyal Bilimlerde Araştırma Yöntemleri, SPSS Uygulamalı. (7. Baskı). Sakarya: Sakarya Yayıncllı.

Atay, L. ve Dilek, S.E. (2013). Konaklama İşletmelerinde Yeşil Pazarlama Uygulamaları: Ibis Otel Örneği. Süleyman Demirel Üniversitesi İktisadi ve İdari Bilimler Fakültesi Dergisi, 18(1): 203-219. 
Ayuso, S. (2007). Comparing Voluntary Policy Instruments for Sustainable Tourism: The Experience of the Spanish Hotel Sector, Journal of Sustainable Tourism, 15(2): 144-159. https://doi.org/10.2167/jost617.0

Bellesi, F., Lehrer, D. and Tal, A. (2005). Comparative Advantage: The Impact of ISO 14001 Environmental Certification on Exports, Environmental Science \& Technology, 39(7): 1943-1953.

Best, M. N. and Thapa, B. (2013). Motives, Facilitators and Constraints of Environmental Management in the Caribbean Accommodations Sector. Journal of Cleaner Production, 52(1): 165175. https://doi.org/10.1016/j.jclepro.2013.03.005

Bohdanowicz, P. (2006). Environmental Awareness and Initiatives in the Swedish and Polish Hotel Industries-Survey Results, Hospitality Management, 25(4): 662-682.

Boyraz, M. (2017). Termal Otel İşletmelerinde Yönetsel Bakış Açısıyla Çevre Yönetimi Uygulamalarının Değerlendirilmesi, Yayımlanmış Yüksek Lisans Tezi, Afyon Kocatepe Üniversitesi, Afyonkarahisar.

Bramwell, B. and Alletorp, L. (2001). Attitudes in The Danish Tourism Industry to The Roles of Business and Government in Sustainable Tourism, The International Journal of Tourism Research, 3(2): 91-103. https://doi.org/10.1002/jtr.242

Büyüköztürk, Ş. (2009). Sosyal Bilimler için Veri Analizi El Kitabı İstatistik, Araştırma Deseni SPSS Uygulamaları ve Yorum (9. Baskı). Ankara: Pegem Yayıncılık.

Chan, E. S. W. (2008). Barriers to EMS in the Hotel Industry, International Journal of Hospitality Management, 27(2): 187-196. https://doi.org/10.1016/j.ijhm.2007.07.011

Chan, E. S. W. and Wong, S.C.K. (2006). Motivations for ISO 14001 in the Hotel Industry, Tourism Management, 27(3): 481-492.

Enz, A. C. and Siguaw, A. J. (1999). Best Hotel Environmental Practices, Cornell Hotel and Restaurant Administration Quarterly, 40(5): 72-7.

Habing, B. (2005). Exploratory Factor Analysis, [Online] http://www.stat.sc.edu/ habing/courses/530/EFA2005.pdf [Erişim Tarihi: 20.05.2021].

Hair, J. F., Black, W. C., Babin B. J. and Anderson, R.E. (1998). Multivariate Data Analysis. New Jersey: Pearson.

Hillary R. (1999). Evaluation of Study Reports on the Barriers, Opportunities and Drivers for Small and Medium-sized Enterprises in the Adoption of Environmental Management Systems. London: Department of Trade and Industry.

Hillary, R. (2004). Environmental Management Systems and The Smaller Enterprise, Journal of Cleaner Production, 12(6): 561-569. https://doi.org/10.1016/j.jclepro.2003.08.006

Hobson, K. \& Essex, S. (2001). Sustainable tourism: A View from Accommodation Businesses, Service Industries Journal, 21(4): 133-146. https://doi.org/10.1080/714005050

http://www.turcev.org.tr/v2/icerikDetay.aspx?icerik_id=94 [Erişim Tarihi: 13.12.2019].

https://www.travelife.info/index_new.php?menu=home\&lang=tr [Erişim Tarihi: 13.12.2019].

https://www.yesillenenoteller.com/projects/ [Erişim Tarihi: 15.12.2019].

https://yigm.ktb.gov.tr/TR-9579/turizm-tesisleri.html [Erişim Tarihi: 20.12.2019].

International Organization for Standardization-ISO (1996). Environmental Management Systems Specification with Guidance for Use. Switzerland: International Organization for Standardization. 
Jabbour, C. J. C., Jabbour, A. B. L. S., Govindan, K., Freitas, T. P., Soubihia, D. F., Kannan, D. and Latan, H. (2016). Barriers to the Adoption of Green Operational Practices at Brazilian Companies: Effects on Green and Operational Performance, International Journal of Production Research, 54(10): 3042-3058, http://dx.doi.org/10.1080/00207543.2016.1154997

Kaiser, H. F. (1974). Littler Jiffy, Mark IV, Educational and Psychology Measurement, 34: 111-117. https://doi.org/10.1177/001316447403400115

Kalaycı, Ş. (2017). Faktör Analizi, (Editör) Şerif K.: SPSS Uygulamalı Çok Değişkenli İstatistik Teknikleri içinde (ss. 321-331), Ankara: Dinamik Akademi.

Kan, A. ve Akbaş, A. (2005). Lise Öğrencilerinin Kimya Dersine Yönelik Tutum Ölçeği Geliştirme Çalışması, Mersin Üniversitesi Eğitim Fakültesi Dergisi, 1(2): 227-237. https://dergipark.org.tr/tr/pub/mersinefd/issue/17391/181763

Kassinis, G. and Soteriou, A. (2003). Greening the Service Profit Chain: The Impact of Environmental Management Practices, Production and Operations Management, 12(3): 386-403.

Kozak, M. (2015). Bilimsel Araştırma: Tasarım, Yazım ve Yayım Teknikleri. (2. Baskı). Ankara: Detay Yayıncilik.

Kültür ve Turizm Bakanlığı (2020). Turizm Tesisleri: Turizm İşletme Belgeli Tesisler 02.11.2020 Tarihli Turizm İstatistikleri, https://yigm.ktb.gov.tr/Eklenti/77200,tib-02112020xls.xls?0 [Erişim Tarihi: 15.11.2020].

Levy, J. I. and Dilwali, K. M. (2000). Economic Incentives for Sustainable Resource Consumption at a Large University: Past Performance and Future Considerations, International Journal of Sustainability in Higher Education, 1(3): 252-266. https://doi.org/10.1108/1467630010352309

Lorcu, F. (2015). Örneklerle Veri Analizi, SPSS Uygulamalı. (1. Baskı). Ankara: Detay Yayıncıllk.

Mak, A. H. N. and Chang, R. C. Y. (2019). The Driving and Restraining Forces for Environmental Strategy Adoption in the Hotel Industry: A Force Field Analysis Approach. Tourism Management, 73: 48-60. https://doi.org/10.1016/j.tourman.2019.01.012

Mariotti, F., Kadasah, N. and Abdulghaffar, N. (2014). Motivations and Barriers Affecting the Implementation of ISO 14001 in Saudi Arabia: An Empirical Investigation, Total Quality $\begin{array}{lllll}\text { Management } \& \quad \text { Business } & \text { Excellence, } & \text { 25(11-12): } & \text { 1352-1364. }\end{array}$ https://doi.org/10.1080/14783363.2014.912038

Martin-Peña, M. L., Diaz-Garrido, E. and Sanchez-Lopez, J. M. (2014). Analysis of Benefits and Difficulties Associated with Firms' Environmental Management Systems: The Case of the Spanish Automotive Industry, Journal of Cleaner Production, 70: 220-230. https://doi.org/10.1016/j.jclepro.2014.01.085

Massoud, M. A., Fayad, R., El-Fadel, M. and Kamleh, R. (2014). Drivers, Barriers and Incentives to Implementing Environmental Management Systems in the Food Industry: A Case of Lebanon, Journal of Cleaner Production, 18: 200-209. https://doi.org/10.1016/j.jclepro.2009.09.022

Nemli, E. (2000). Çevreye Duyarl İşletmecilik ve Türk Sanayiinde Çevre Yönetim Sistemi Uygulamalar. İstanbul: İstanbul Sanayi Odası, Çevre Şubesi.

Öksüz, E. ve Malhan, S. (2005). Sağhl̆ğa Bağ̆ı Yaşam Kalitesi-Kalimetri, Ankara: Başkent Üniversitesi.

Pinzone, M., Lettieri, E. and Masella, C. (2015). Proactive Environmental Strategies in Healthcare Organisations: Drivers and Barriers in Italy, Journal of Business Ethics, 131: 183-197. https://doi.org/10.1007/s10551-014-2275-8 
Post, J. E. and Altman, B. W. (1994). Managing the Environmental Change Process: Barriers and Opportunities, Journal of Organizational Change Management, 7(4): 64-81. https://doi.org/10.1108/09534819410061388

Preacher, K. J. and MacCallum, R. C. (2002). Exploratory Factor Analysis in Behavior Genetics Research: Factor Recovery with Small Sample Size, Behavior Genetics, 32(2): 153-161.

Quazi, H. A. (1999). Implementation of an Environmental Management System: The Experience of Companies Operating in Singapore. Industrial Management \& Data Systems, 99(7): 302-311. https://doi.org/10.1108/02635579910262526

Santos, G., Rebelo, M., Lopes, N., Alves, M. R. and Silva, R. (2016). Implementing and Certifying ISO 14001 in Portugal: Motives, Difficulties and Benefits After ISO 9001 Certification, Total Quality Management, 27(11): 1211-1223, http://dx.doi.org/10.1080/14783363.2015.1065176

Scherer, R. F., Wiebe, F. A., Luther, D. C. and Adams, J. S. (1988). Dimensionality of Coping: Factor Stability Using the Ways of Coping Questionnaire, Psychological Reports, 62(3), 763-770.

Schermelleh-Engel, K., Moosbrugger, H. and Müller, H. (2003). Evaluating The Fit of Structural Equation Models: Tests of Significance and Descriptive Goodness-of-Fit Measures, Methods of Psychological Research Online, 8(2): 23-74.

Shi, H., Peng, S. Z., Lui, Y. and Zhong, P. (2008). Barriers to the Implementation of Cleaner Production in Chinese SMEs: Government, Industry and Expert Stakeholders' Perspectives, Journal of Cleaner Production, 16(7): 842-852. https://doi.org/10.1016/j.jclepro.2007.05.002

Stabler, M. J. and Goodall, B. (1997). Environmental Awareness, Action and Performance in The Guernsey Hospitality Sector, Tourism Management, 18(1): 19-33. https://doi.org/10.1016/S02615177(96)00095-7

Tabachnick, B. G. and Fidell, L. S. (2013). Using Multivariate Statistics. (6 ${ }^{\text {th }}$ Edition). Harlow, Essex: Pearson Education.

Tavşancıl, E. (2002). Tutumların Ölçülmesi ve SPSS ile Veri Analizi. Ankara: Nobel Yayın Dağıtım.

Toprak, Z. (2012). Çevre Yönetimi ve Politikası. (3. Bask1). İzmir: Albi Yayınları, 271- 291.

Van De Vijver, F. and Hambleton, R. (1996). Translating Tests: Somer Practical Guidelines, European Psychologist, 1(2): 89-99.

Vernon, J., Essex, S., Pinder, D. and Curry, K. (2003). The "Greening" of Tourism MicroBusinesses: Outcomes of Focus Group Investigations in South East Cornwall, Business Strategy and The Environment, 12(1): 49-69. https://doi.org/10.1002/bse.348

Yaşlığlu, M. M. (2017). Sosyal Bilimlerde Faktör Analizi ve Geçerlilik: Keşfedici ve Doğrulayıcı Faktör Analizlerinin Kullanılması, İstanbul Üniversitesi İşletme Fakültesi Dergisi, 46(Özel Sayı), 7485.

Yusof, Z. B. and Jamaludin, M. (2014). Barriers of Malaysian Green Hotels and Resorts, Procedia Social and Behavioral Sciences, 153: 501-509. https://doi.org/10.1016/j.sbspro.2014.10.083 